\title{
Desain Pembelajaran Inkuiri dengan Skema Online Terintegrasi Aktivitas Argumentasi: Analisis Capaian Pengetahuan Konseptual dan Respon Mahasiswa Calon Guru IPA
}

\author{
Siswanto Siswanto ${ }^{1 *}$, Zuida Ratih Hendrastuti ${ }^{2}$, Lusida Kiswari ${ }^{3}$, Fina Al Fatikhiah ${ }^{4}$ \\ ${ }^{1,3,4 P}$ Program Studi Pendidikan IP A, Univeritas Tidar \\ ${ }^{2}$ Program Studi Pendidikan Matematika, Univeritas Tidar \\ *Correspondence Address: siswanto@untidar.ac.id
}

\begin{abstract}
This research was conducted because the importance of the online learning process in order to keep it done with an emphasis on student activities to construct knowledge independently. This study aims to analyze conceptual knowledge and student responses to science teacher candidates when implementing an online inquiry learning process by integrating scientific argumentation activities. This research was used quantitative approach with pre-experiment design. The research activity was carried out by first determining the learning design, then applying the learning design to the students, totaling 38 students. In this study, a pretest and posttest were conducted to obtain data on the achievement of student conceptual knowledge. In addition, students also fill out a questionnaire to get student data responses to the learning process being carried out. The results showed that the learning activities carried out were able to increase the conceptual knowledge of students in the high category. In addition, the learning process generally received a positive response from students. The learning process is carried out in three sessions. The first session consisted of problem identification, conducting literature studies, and formulating bypotheses with provisional arguments. The second session consisted of investigation, data analysis, evaluation, evaluation and argumentation. The third session consisted of activities to communicate the experimental results.
\end{abstract}

Keyword: inquiry learning, argumentation activity, online schema on inquiry, conceptual knowledge, students responses.

\begin{abstract}
ABSTRAK
Penelitian ini dilakukan karena melihat pentingnya proses pembelajaran online agar tetap dilakukan dengan menitikberatkan pada aktivitas mahasiswa untuk mengkonstruksi pengetahuan secara mandiri dan bermakna. Penelitian ini bertujuan untuk menganalisis capaian pengetahuan konseptual dan respon mahasiswa calon guru IPA ketika diterapkan proses pembelajaran inkuiri yang di desain secara online dengan mengintegrasikan aktivitas argumentasi ilmiah. Penelitian ini dilakukan menggunakan pendekatan kuantitatif dengan desain penelitian pre-eksperimen. Kegiatan penelitian dilakukan dengan merancang terlebih dahulu desain pembelajaran, kemudian menerapkan desain pembelajaran kepada mahasiswa, sebanyak 38 mahasiswa. Pada penelitian ini dilakukan pretest dan posttes untuk mendapatkan data capaian pengetahuan konseptual mahasiswa. Selain itu juga mahasiswa mengisi kuesioner untuk mendapatkan data respon mahasiswa terhadap proses pembelajaran yang dilakukan. Hasil penelitian menunjukkan bahwa kegiatan pembelajaran yang dilakukan mampu meningkatkan pengetahuan konseptual mahasiswa dengan kategori tinggi. Selain itu, proses pembelajaran yang dilakukan secara umum mendapat respon yang positif dari mahasiswa. Proses pembelajaran dilakukan dalam tiga sesi. Sesi pertama terdiri dari aktivitas mengidentifikasi masalah, melakukan studi literatur, dan merumuskan hipotesis dengan disertai argumentasi sementara. Sesi kedua terdiri dari aktivitas penyelidikan, analisis data, dan melakukan evaluasi hipotesis serta argumentasi sementara. Sesi ketiga terdiri dari aktivitas mengkomunikasikan hasil eksperimen.
\end{abstract}

Kata kunci: pembelajaran inkuiri, aktivitas argumentasi, inkuiri dalam skema online, pengetahuan konseptual, respon mahasiswa. 


\section{PENDAHULUAN}

Saat ini, kemajuan teknologi membuat perubahan di segala aspek kehidupan, salah satunya dalam aspek kegiatan pendidikan. Pada kegiatan pendidikan, proses pembelajaran online menjadi sebuah keniscayaan. Pembelajaran online menjadi sangat penting untuk dikembangkan saat ini (Garrison, 2000). Proses pembelajaran yang dilakukan secara online memiliki beberapa manfaat, yaitu dapat diakses secara terbuka, tidak terhalang waktu dan jarak (Biao, 2012).

Pentingnya pembelajaran online bertolak belakang dengan realisasi yang terjadi di lapangan. Berdasarkan hasil penelitian, proses pembelajaran yang dilakukan secara online kurang efektif dalam meningkatkan hasil belajar yang sesuai prinsip pembelajaran abad 21, salah satunya adalah penguasaan konseptual pada level berpikir tingkat tinggi (Musingafi, 2015; Arinto, 2016).

Selain didasarkan pada studi literatur, peneliti juga melakukan observasi lapangan dengan melakukan wawancara terhadap pengajar yang pernah melaksanakan pembelajaran online pada subjek materi IPA. Temuan menunjukkan bahwa sangat sulit melakukan proses pembelajaran online yang mampu memfasilitasi penguasaan konsep, terutama pada aspek kemampuan konseptual level tinggi. Selama ini, penguasaan hasil belajar hanya mampu dicapai pada aspek keterampilan berpikir tingkat rendah. Padahal, sangat penting memfasilitasi mahasiswa untuk menguasai pengetahuan konseptual pada level berpikir tingkat tinggi (Zohar, 2003; Miller, 2013; Karim, 2018). Penguasaan konseptual terutama pada level berpikir tingkat tinggi penting untuk dilatihkan dalam proses pembelajaran karena hal tersebut secara langsung mampu melatihkan mahasiswa untuk menyelesaikan permasalahan-permasalahan kontekstual (Heong, 2012). Selain itu, proses pembelajaran online yang dirancang juga kurang mendapatkan respon yang positif dari mahasiswa (Saido, 2018). Hal ini ditandai dengan partisipasi mahasiswa yang rendah dalam proses pembelajaran online.

Berdasarkan masalah yang sudah dipaparkan perlu adanya sebuah inovasi dalam proses pembelajaran online yang mampu melatihkan mahasiswa untuk memiliki pengetahuan konseptual secara utuh baik dari aspek level berpikir tingkat rendah maupun level berpikir tingkat tinggi. Pada penelitian ini, inovasi yang dikembangkan yaitu dengan mengintegrasikan aktivitas argumentasi ke dalam pembelajaran inkuiri yang aktivitasnya dirancang secara online.

Kegiatan inkuiri yang dilakukan dalam proses pembelajaran mampu melatihkan penguasaan konseptual mahasiswa secara komprehensif (Wenning, 2011; Harlen 2014). Selain itu, tahapan-tahapan dalam kegiatan inkuiri mampu melatih mahasiswa untuk berpikir dan bertindak seperti seorang ilmuwan. Sedangkan, integrasi aktivitas argumentasi yang dilakukan bertujuan untuk lebih memudahkan mahasiswa dalam menguasai capaian belajar yang diharapkan, yaitu dimensi pengetahuan konseptual. Hasil riset menunjukkan bahwa proses pembelajaran yang melatihkan aktivitas argumentasi, dapat lebih meningkatkan kemampuan mahasiswa untuk mengkonstruksi konsep (Muslim, 2012; Siswanto, 2014).

Penelitian ini, akan dilakukan pada perkuliahan matematika IPA. Hal ini dilakukan karena selama ini proses pembelajaran matematika untuk mahasiswa IPA yang dilakukan secara online kurang memfasilitasi mahasiswa untuk berpikir dan bertindah seperti seorang ilmuwan. Aktivitasaktivitas penyelidikan dalam proses pembelaran kurang ditekankan, sehingga menimbulkan kebosanan bagi mahasiswa. Padahal, konsep-konsep matematika yang diajarkan kepada mahasiswa IPA dilakukan dengan menghubungkan fenomena-fenomena IPA untuk dianalisis gejalanya berdasarkan tinjauan matematisnya. Konsep matematika yang dipelajari digunakan sebagai alat untuk menjelaskan fenomena tersebut. Oleh sebab itu, diperlukan proses berinkuiri untuk menganalisis fenomena yang dipelajari.

Berdasarkan hal tersebut, penelitian ini dilakukan untuk menganalisis bagaimana capaian pengetahuan konseptual dan respon mahasiswa calon guru IPA ketika diterapkan proses 
pembelajaran inkuiri yang di desain secara online dengan mengintegrasikan aktivitas argumentasi ilmiah.

\section{METODOLOGI}

Gambar 1 menyajikan tahapan penelitian yang dilakukan. Pendekatan kuantitatif dengan desain pre-experiment digunakan dalam penelitian ini. Peneliti merancang desain tahapan aktivitas inkuiri yang akan dilakukan secara online. Kemudian setelah mendesain tahapan pembelajaran, peneliti melakukan pretest kepada mahasiswa. Lalu, setelah dilakukan pretest, menerapkan tahapan pembelajaran yang sudah dirancang pada perkuliahan matematika IPA. Selanjutnya dilakukan posttest. Selain itu, juga dibagikan angket untuk menggali respon mahasiswa terkait proses pembelajaran yang sudah dilakukan. Proses pembelajaran dilakukan pada topik "Gerak Parabola". Pada topik ini, mahasiswa dilatih untuk menguasai konsep turunan, menggambarkan grafik parabola, dan menganalisis koordinat sebuah objek yang bergerak parabola.

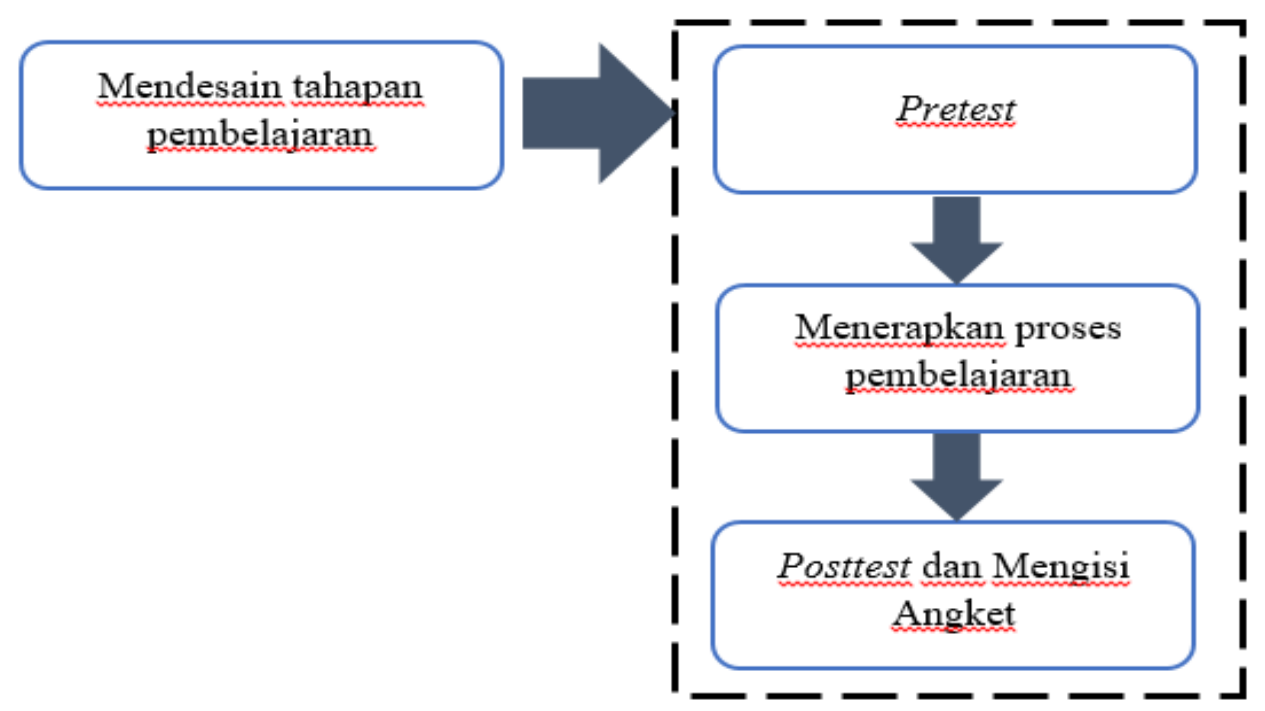

Gambar 1. Desain Penelitian

Pada penelitian ini, sebanyak 38 mahasiswa menjadi partisipan. Keseluruhan mahasiswa tersebut mengikuti seluruh proses pembelajaran yang dilakukan. Instrumen yang digunakan untuk mengukur capaian penguasaan konseptual berupa instrument tes esai menggunakan rubrik penilaian, sedangkan untuk mengukur respon mahasiswa menggunakan kuesioner.

Analisa data capaian penguasaan pengetahuan konseptual dilakukan dengan beberapa tahapan yaitu: (1) menghitung skor pretes dan postes setiap mahasiswa, (2) menghitung nilai gain ternormalisasi setiap mahasiswa, (3) melakukan perhitungan rata-rata dari skor pretest dan posttest seluruh mahasiswa, (4) menghitung nilai gain yang ternormasilisasi $<\mathrm{g}\rangle$ menggunakan persamaan (1), (4) menetapkan keriteria peningkatan, yaitu tinggi $(<\mathrm{g}>\geq 0,7)$, cukup $(0,7<<$ g $>\geq 0,3)$, rendah $(<\mathrm{g}><0,3)$. Analisa data respon mahasiswa dilakukan dengan menghitung persentase jumlah mahasiswa yang menjawab ya dan tidak dan menganalisisnya secara deskriptif.

$$
<g>=\frac{(\text { skor rerata posttest })-(\text { skor rerata pretest })}{(\text { skor ideal })-(\text { skor rerata pretest })}
$$




\section{TEMUAN DAN PEMBAHASAN}

Proses pembelajaran inkuiri dalam penelitian ini di desain secara online. Pada penelitian ini, proses pembelajaran inkuiri yang didesain diintegrasikan dengan aktivitas argumentasi. Langkah pembelajaran inkuiri yang didesain secara online dengan terintegrasi aktivitas argumentasi disajikan pada Tabel 1. Secara umum, tahapan pembelajaran dikemas dalam 3 sesi online. Sesi pertama dilakukan dengan tujuan untuk memfokuskan mahasiswa pada materi yang akan dipelajari, serta mempersiapkan mahasiswa untuk mencari teori/konsep yang terkait dengan masalah yang akan dipelajari. Sesi kedua dilakukan untuk pemerolehan pengetahuan. Sesi ketiga dilakukan untuk penguatan atas pengetahuan yang sudah diperoleh. Lebih jelasnya dapat dilihat pada Tabel 1. berikut.

Tabel 1. Langkah Pembelajaran

\begin{tabular}{|c|c|}
\hline Langkah Pembelajaran & Aktivitas Mahasiswa \\
\hline \multicolumn{2}{|c|}{ SESI 1} \\
\hline Mengidentifikasi masalah & $\begin{array}{l}\text { - Melakukan identifikasi masalah } \\
\text { - Melakukan proses konsultasi untuk mengevaluasi hasil } \\
\text { identifikasi masalah }\end{array}$ \\
\hline Melakukan studi literatur & $\begin{array}{l}\text { - Melakukan studi literature yang berkaitan dengan masalah } \\
\text { yang dipaparkan } \\
\text { - Mengkaji literatur tersebut }\end{array}$ \\
\hline $\begin{array}{lccr}\text { Merumuskan } & \text { hipotesis } & \text { dengan } & \text { disertai } \\
\text { argumentasi } & \text { sementara } & \text { (pembenaran } & \text { atas } \\
\text { hipotesis) } & & & \end{array}$ & $\begin{array}{l}\text { Merumuskan hipotesis dalam bentuk klaim disertai dengan } \\
\text { pemberian bukti, pembenaran, dan dukungan sementara }\end{array}$ \\
\hline \multicolumn{2}{|c|}{ SESI 2} \\
\hline $\begin{array}{l}\text { Melakukan penyelidikan untuk menguji hipotesis } \\
\text { berbasis aktivitas argumentasi }\end{array}$ & $\begin{array}{l}\text { - Melakukan eksperimen virtual untuk menguji hipotesis } \\
\text { (bantuan simulasi PHET) }\end{array}$ \\
\hline Melakukan analisis data & $\begin{array}{l}\text { - Melakukan analisa data hasil eksperimen sebagai dasar } \\
\text { dalam mengevaluasi hipotesis }\end{array}$ \\
\hline Melakukan evaluasi hipotesis & $\begin{array}{l}\text { - Melakukan evaluasi atas hipotesis yang diajukan disertai } \\
\text { dengan argumentasi yang tepat }\end{array}$ \\
\hline \multicolumn{2}{|r|}{ SESI 3} \\
\hline Mengkomunikasikan hasil & $\begin{array}{l}\text { - Setiap kelompok memaparkan hasil eksperimen yang } \\
\text { dilakukan secara daring }\end{array}$ \\
\hline
\end{tabular}

Hasil penguasaan konseptual mahasiswa secara umum ada pada kategori peningkatan yang tinggi dengan nilai gain yang ternormalisasi sebesar 0,75 . Berdasarkan data yang diperoleh, rata-rata skor pretest dan posttest mahasiswa sebesar 29,47 dan 82,24. Gambar 2 menyajikan sebaran peningkatan penguasaan konseptual mahasiswa. Berdasarkan gambar 2, proses pembelajaran yang dilakukan secara umum mampu memberikan dampak terhadap peningkatan konseptual mahasiswa yang cukup efektif. Sebanyak 11 mahasiswa mendapatkan kategori peningkatan yang cukup, sedangkan 27 mahasiswa mendapatkan kategori peningkatan yang tinggi. 


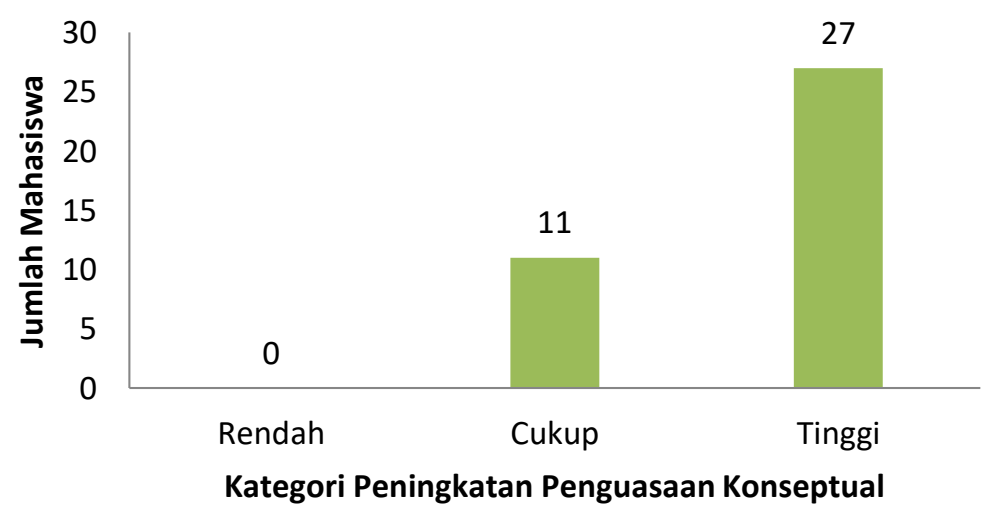

Gambar 2. Jumlah Mahasiswa di Setiap Kategori Peningkatan

Efektifitas peningkatan penguasaan konseptual disebabkan karena proses pembelajaran yang diterapkan. Pada pembelajaran inkuiri, mahasiswa difasilitasi untuk mengkonstruksi pengetahuannya melalui aktivitas proses ilmiah yang bermakna (Wenning, 2011). Proses pembelajaran berbasis inkuiri memiliki beberapa manfaat diantaranya dapat membangun pengetahuan mahasiswa dari level kognisi rendah sampai level kognisi yang tinggi (Wenning, 2011; Harlen, 2014). Selain itu, melalui proses inkuiri mahasiswa dilatih keterampilan intelektualnya (Kai WU, 2006).

Selain tahapan inkuiri, kegiatan argumentasi yang dipadukan dalam pembelajaran inkuiri juga memberikan peran dalam meningkatkan capaian pengetahuan konseptual mahasiswa. Berdasarkan hasil penelitian, mahasiswa akan semakin cakap dalam mengkonstruksi pengetahuan jika kemampuan membangun argumentasi ilmiahnya juga baik (Muslim, 2012; Siswanto, 2014; Febriastuti, 2017). Keterampilan berargumentasi dibutuhkan mahasiswa untuk memperkuat pemahamannya terhadap suatu konsep tertentu (Erduran, 2008; Sampson, 2010; Yusiran, 2016; Gumilar, 2018). Pada proses pembelajaran ini, aktivitas argumentasi yang dilakukan merujuk pada pola argumentasi yang dirumuskan oleh Toulmin, mencakup pengajuan klaim, bukti, pembenaran, dan dukungan (Toulmin, 2003).

Selain capaian penguasaan pengetahuan konseptual, pada penelitian ini juga digali respon mahasiswa terkait proses pembelajaran yang dilakukan. Berdasarkan hasil penelitian yang sudah dilakukan, mahasiswa memberikan respon yang positif terhadap proses pembelajaran yang diterapkan. Rekapitulasi hasil respon mahasiswa dapat dilihat pada Gambar 4, dengan butir-butir pernyataan seperti pada Tabel 2 .

Tabel 2. Daftar Pertanyaan

\begin{tabular}{cl}
\hline No & \multicolumn{1}{c}{ Butir Pertanyaan } \\
\hline 1 & Apakah aktivitas pembelajaran yang dilakukan merupakan hal yang baru bagi anda? \\
\hline 2 & Apakah anda kesulitan dalam melakukan aktivitas pembelajaran tersebut? \\
\hline 3 & Apakah aktivitas pembelajaran yang dilakukan membuat anda tertarik untuk belajar matematika? \\
\hline 4 & $\begin{array}{l}\text { Apakah proses pembelajaran yang dilakukan lebih menyenangkan dari pada pembelajaran tatap muka yang } \\
\text { biasa anda lakukan? }\end{array}$ \\
\hline 5 & $\begin{array}{l}\text { Apakah kegiatan pembelajaran yang dilakukan lebih memudahkan anda untuk menguasai konsep-konsep } \\
\text { matematika? }\end{array}$ \\
\hline 6 & Apakah kegiatan eksperimen yang ada dalam aktivitas pembejaran, membosankan? \\
\hline
\end{tabular}




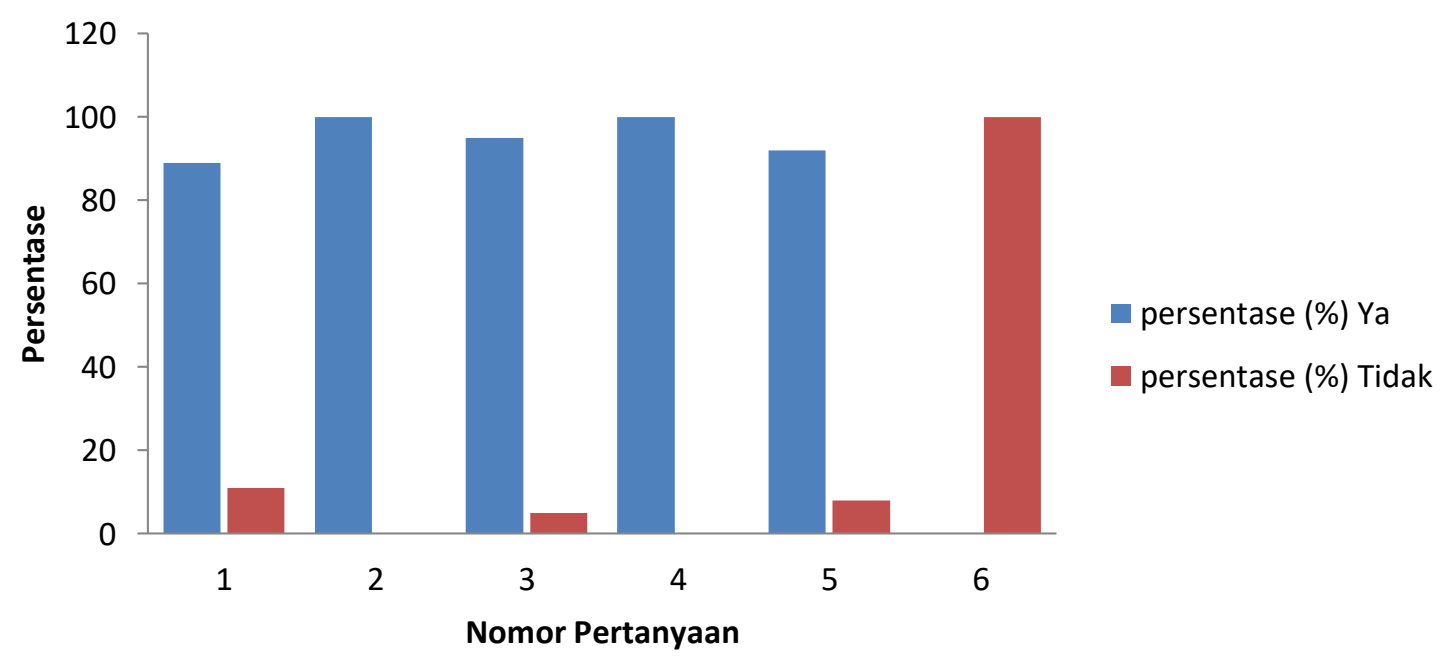

Gambar 4. Persentase Respon Mahasiswa terhadap Kegiatan Eksperimen

Pada poin pertanyaan nomor 1, sebanyak $89 \%$ mahasiswa mengatakan bahwa aktivitas yang dilakukan dalam proses pembelajaran merupakan hal yang baru bagi mereka. Sementara 11\% mahasiswa mengatakan bahwa kegiatan pembelajaran yang dilakukan bukan merupakan hal baru bagi mereka. Hal baru yang dirasakan dalam proses pembelajaran ini adalah aktivitas online yang dilakukan dengan menitikberatkan pada proses inkuiri dan argumentasi ilmiah. Selain itu, juga dikarenakan penggunaan eksperimen virtual yang dilakukan dalam kegiatan pembelajaran. Mahasiswa merasa bahwa kegiatan eksperimen yang dilakukan tidak membosankan (Poin pertanyaan nomor 6). Berdasarkan jawaban respon mahasiswa, aktivitas-aktivitas yang dilakukan juga tidak memberikan kesulitan. Berdasarkan pertanyaan pada poin nomor 2, pembelajaran inkuiri yang dikemas secara online dengan memadukan aktivitas argumentasi mudah untuk dilakukan.

Selanjutnya untuk poin nomor 3, 95\% mahasiswa berpendapat bahwa aktivitas pembelajaran yang dilakukan membuat mahasiswa tertarik mempelajari konsep IPA yang ditinjau dari persamaan matematisnya. Berdasarkan temuan, hanya 5\% mahasiswa yang merasa tidak tertarik. Pada umumnya, ketertarikan mahasiswa disebabkan karena persamaan-persamaan matematis dipelajari secara kontekstual dengan menghubungkannya langsung melalui fenomena. Hal ini juga menyebabkan mahasiswa merasa senang dalam melakukan proses pembelajaran. Berdasarkan temuan (pada poin pertanyaan nomor 4), seluruh mahasiswa di dalam kelas merasa bahwa proses pembelajaran yang dilakukan menyenangkan.

Pertanyaan nomor 5, 92\% responden menyatakan bahwa konsep yang dipelajari lebih mudah untuk dikuasai. Adanya kegiatan eksperimen yang dilakukan membuat mahasiswa lebih bisa menguasai konsep yang diajarkan. Selain itu, aktivitas argumentasi ilmiah yang dilakukan memudahkan mahasiswa mengkonstruksi konsep secara utuh. Berdasarkanhasil temuan, 8\% mahasiswa memilih jawaban tidak. Hal ini disebabkan karena mahasiswa merasa kesulitan mengkonstruksi konsep melalui kegiatan argumentasi. Oleh sebab itu, perlu latihan lebih banyak untuk membangun argumentasi ilmiah.

\section{SIMPULAN}

Berdasarkan temuan penelitian, dapat disimpulkan bahwa kegiatan pembelajaran inkuiri yang dikemas secara online dengan memadukan aktivitas argumentasi ilmiah mampu meningkatkan penguasaan pengetahuan konseptual mahasiswa dengan kategori tinggi. Secara keseluruhan, proses pembelajaran yang dilakukan mendapatkan respon yang positif dari mahasiswa. Proses pembelajaran inkuiri yang dikemas secara online dengan memadukan kegiatan 
argumentasi dilakukan dalam tiga sesi. Sesi pertama terdiri dari aktivitas mengidentifikasi masalah, melakukan studi literatur, dan merumuskan hipotesis dengan disertai argumentasi sementara. Sesi kedua terdiri dari aktivitas penyelidikan, analisis data, dan melakukan evaluasi hipotesis dan argumentasi sementara. Sesi ketiga terdiri dari aktivitas mengkomunikasikan hasil eksperimen. Berdasarkan hasil tersebut, perlu dilakukan penelitian-penelitian lanjutan untuk melakukan uji coba pembelajaran inkuiri yang memadukan aktivitas argumentasi untuk melatihkan keterampilan-keterampilan berpikir tingkat tinggi.

\section{PENGHARGAAN}

Peneliti mengucapkan terimakasih kepada Kementerian Riset dan Teknologi Republik Indonesia yang sudah memberikan dana penelitian dalam bentuk hibah sehingga kegiatan penelitian ini dapat terlaksana.

\section{REFERENSI}

Arinto, P. B. (2016). Issues and Challenges in Open and Distance E-Learning: Perspectives from the Philippines. The International Review of Research in Open and Distributed Learning, 17(2).

Biao, I. (2012). Open and Distance Learning: Achievements and Challenges in a Developing SubEducational Sector in Africa. In Distance Education. Intech.

Erduran, S., \& Maria, P. (2008). Argumentation in Science Education. London: Spinger Science.

Febriastuti, Y. D. (2017). Inovasi Model Pembelajaran Guided Inquiry untuk Meningkatkan Kemampuan Kognitif Siswa SMP. Indonesian Journal of Science and Education, 1(1), 4956.

Garrison, R. (2000). Theoretical Challenges for Distance Education in the 21st century: A shift from Structural to Transactional Issues. The International Review of Research in Open and Distributed Learning, 1(1).

Gumilar, S., \& Subali, B. (2018, March). Scientific Method by Argumentation Design: Learning Process for Maintaining Student's Retention. in Journal of Physics Conference Series (Vol. 983, No. 1, p. 012021).

Harlen, W. (2014). Helping children's development of inkuiri skills. Inkuiri in primary science education (IPSE), 1: 5-19.

Heong, Y. M., Yunos, J. M., Othman, W., Hassan, R., Kiong, T. T., \& Mohamad, M. M. (2012). The Needs Analysis of Learning Higher Order Thinking Skills for Generating Ideas. Procedia-Social and Behavioral Sciences, 59, 197-203.

Kai Wu, H. (2006). Developing Sixth Graders' Inkuiri Skills to Construct Explanations in Inkuiribased Learning Environments. International Journal of Science Education, 28 (11): 12891313.

Karim, F. A., Kayar, R., Cheng, T. J., \& Sopah, F. M. (2018). Readiness In Applying Higher Order Thinking Skills After Attending Courses. Human Sustainability Procedia. 
Miller, S. (2012, August). Developing Higher Order Thinking Skills. in Proceedings of The Australian Conference on Science and Mathematics Education (formerly UniServe Science Conference).

Musingafi, M. C., Mapuranga, B., Chiwanza, K., \& Zebron, S. (2015). Challenges for Open and Distance Learning (ODL) Students: Experiences from Students of the Zimbabwe Open University. Journal of Education and Practice, 6(18), 59-66.

Muslim, Suhandi, A. (2012). Pengembangan Perangkat Pembelajaran Fisika Sekolah untuk Meningkatkan Kemampuan kognitif dan Keterampilan Berargumentasi. Jurnal Pendidikan Fisika Indonesia, 8:174-183.

Saido, G. M., Siraj, S., Nordin, A. B. B., \& Al_Amedy, O. S. (2018). Higher order thinking skills among secondary school students in science learning. MOJES: Malaysian Online Journal of Educational Sciences, 3(3), 13-20.

Sampson, V., \& Gerbino, F. (2010). Two Instructional Models That Teacher Can Use to Promote \& Support Scientific Argumentation In the Biology Classroom. The American Biology Teacher, 72 (7): 427-431.

Siswanto. (2014). Penerapan Model Pembelajaran Pembangkit Argumen Menggunakan Metode Saintifik untuk Meningkatkan Kemampuan Kognitif dan Keterampilan Berargumentasi Siswa. Jurnal Pendidikan Fisika Indonesia, 10 (2): 104-116.

Toulmin, S. (2003). The Uses of Argument. New York: Cambridge University Press.

Wenning, C., J. (2011). Experimental inkuiri in introductory physics courses. Journal of Physics Teacher Education, 6 (2): 2-8.

Yusiran, Y., \& Siswanto, S. (2016). Implementasi Metode Saintifik Menggunakan Setting Argumentasi pada Mata Kuliah Mekanika untuk Meningkatkan Kemampuan Kognitif Mahasiswa Calon Guru Fisika. Jurnal Penelitian \& Pengembangan Pendidikan Fisika, 2(1), 15-22.

Zohar, Anat, and Yehudit J. Dori. "Higher order thinking skills and low-achieving students: Are they mutually exclusive?." The journal of the learning sciences 12.2 (2003): 145-181. 